Pp.153-161

\title{
Exploring the Postcolonial Concept through the Eye of European Expansionism and Imperialism
}

\author{
Waleed Hamad \\ Department of English Language and Literature \\ Faculty of English, College of Languages, Salahaddin University-Erbil \\ Erbil, Iraq \\ Email: unilecturer222@gmail.com
}

Received: 9/13/2021 Accepted:10/20/2021 Published: 10/25/2021

Abstract:

The Postcolonial study has become very popular - it deals with colonial issues, cultural hegemony, imperialist subjects, and subservient topics. The postcolonial analysis mainly mostly involves Africa, America, Asia, and the Middle East. The imperial forces like England and France were the prominent actors in this venture. Thus, the postcolonial began after these imperial forces had left their former colonies. The formerly colonized countries were given political independence, and they began to govern themselves. However, the postcolonial study began to gain significant attention from Edward Said's Orientalism (1978), in which he explains how Africa, the Middle East, and Asia were established on the western Imperialist structure. Edward Said explains exclusively that Orientalism vehemently accentuates the disparity between the west, their theories, social orders, literary pieces, the orient political history, tradition, norms, ideology, religion, and destiny. It dramatically reflects how the colonized adapted the cultural identity of their colonizers. The postcolonialism has been used to remember a set of conjectures and practices - and it also explains how colonialism has become a prominent and constant record. This article explores the postcolonial study, delineates the available resources that present the idea of postcolonialism, colonialism, and the effect of the Western imperialist system on the former colonies. The article also reflects Homi Bhabha's cultural hybridity; he explains how mimicry plays a significant role in making the colonized adopt the culture of their colonizers.

Keywords: Colonialism, European expansionism, imperialism, other, Orient, postcolonialism

Cite as: Hamad, W. (2021). Exploring the Postcolonial Concept through the Eye of European Expansionism and Imperialism. Arab World English Journal for Translation \& Literary Studies 5 (4) 153-161. DOI: http://dx.doi.org/10.24093/awejtls/vol5no4.11 


\section{Introduction}

The Postcolonial study has drawn so much attention, and so many researchers 31 in the field of literature have contributed to its development. In exploring the nature of postcolonial literary developments, there is a need to accentuate the effects of colonial systems on the colonized. Scholars tend to investigate the socio-political essence of postcolonial events, mainly as it is reflected in literature. Talking about postcolonial literature, it is very pertinent to understand that postcolonial writers have one way or the other drawn attention of the people to the system applied in the postcolonial era. Many comparisons have been made in confinement with socio-political situations of both during and after colonial rule. De Castro pontificates that "Colonialism, understood provisionally as the European annexation and administration of lands and populations in the Americas, Africa, and Asia, has been intertwined with science, technology, and ethics since the Renaissance" (2014, p. 383). Thus, this article examines the progression of postcolonial study and simultaneously reflects on European expansionism, which serves as the tributary of colonialism. Therefore, the problem that this paper tends to solve is the complex reality about the transition from European expansionism to colonialism. The progression between these crucial stages and those components that represent the colonized interest haven't been vehemently brought under focus in postcolonial studies. Also, the subaltern has not been able to speak about their problem and their welfare. Knowing how the subaltern should speak and the language through which their voice could be heard and understood has not been given cogent attention.

\section{Literature Review}

\section{The Accentuation and Progression of Postcolonial Study}

Before presenting the indispensability of postcolonial literary progression, it is crucial to acknowledge that colonization has also played significant roles in European territorial expansion to other parts of the world - especially the East, Middle East, Africa, and the Americas. Hence, this section intends to evaluate some critical texts which reflect the colonial and postcolonial literary views. However, the issue of colonialism is a prominent issue that has been significantly treated globally. Hence, this accentuates the exploration of the European voyages which took place between the 18th and 19th centuries. The journeys they have undergone led to the intensive scientific investigation of the human race (Sen, 2016, p.609). Therefore, this aspect of the study pervasively deals with the colonial system in diverse ways. It also deals with how colonial ideas, decolonization, the hybridity of culture and linguistic application evolved. It also emphasizes on the superior culture and race; and the effect of the colonial system in the invaded territories. Colonial structure was basically based on territorial and economic expansionism. The tendency to improve the commercial power led to the European using military and scientific authority to establish their territories in the invaded spatial landscape (Abu-Lughod, 1991).

However, the concept of postcolonialism is a critical topic among the scholars in the last decades. Also, by the second half of the 20th century, the idea of Nation-State had become a norm in the part of the world that was once under the colonial power of Europe (Anderson, 2000, p. 143). Therefore, those countries colonized by the European power took the independence movement as a ladder to climb into the creation of a Nation-State - especially in a place like Africa (Armesto, 2006, p. 20). Most of the colonized countries were motivated by many factors surrounding them, and this made them consider the struggle to gain independence as a crucial 
decision. But the criticism of nation and nationalism has compelled us to see beyond the current political convention of Nation-State (Arnod, 2002, p. 13). Meanwhile, the concept of colonialism arose when the European power began to invade other countries, manage them, and try to have absolute control over the natives. They dominated their environment and their natural resources; in the process of acclimatizing to colonial knowledge, the machine has been dramatically used as a measure of men (Crusby, 2003, p. 20). Around the 18th-19th centuries, the Europeans had traveled across the globe, and they discovered that there was no indigenous literary documentation in most of the places they visited. For this reason, they assumed that there was no scientific, philosophical knowledge, and technological development in those places they invaded (Donkin, 2003, p. 12).

The European adventurers thought they had a superior civilizing culture than those indigenous people. They had philosophical learning, technological development, andwriting prowess (Brook, 2007, p. 26). They had machines and a very conducive social milieu. At that time, nature was still very considered as something significantly powerful, and it was a danger to peaceful human existence. Therefore, it became a strong standpoint that nature needed to be domesticated. Mignolo opines that "Seed's "Colonial and Postcolonial Discourse" raises two specific topics. The introduction and conclusion are devoted to placing colonial discourse into contemporary scholarship and tracing its debts, complicities, and differences with poststructuralism, subaltern studies, new historicism, and feminist theory" (Mignolo, 1993, p. 120). Hence, looking at the Nation-State from the political angle, we will discover that it has become a global political convention. But we should realize that there have been solid, and intelligent critics of this concept of nation and nationalism (Ashcroft et al., 2013, p. 177). Therefore, those critics have made us realize that it is essential to see beyond the angle of nation and nationalism. In this sense, if one should examine Homi Bhabha's work, one will understand other human perspicacity of postcolonial milieu and see it beyond the level of Nation-State. However, it is important, to begin with hybridity.

The concept of hybridity here takes the prominent aspect of Homi Bhabha's work (Huddart, 2006, p. 23). One of the pertinent concepts of Bhabha's work is mimicry; this also plays a very significant role in his work. As this continues, we will discover the indispensability of the idea of nationalism and thought for human understanding. However, Bhabha has been a great scholar who has developed several concepts on literary studies and two other literary icons Edward Said and Gayatri Chakravorty Spivak (Genoni, 2004,p.23). Some of the most important aspects of his postcolonial theory are the collection of essays titled The Location of Culture (1994), The Black Savant and the Dark Princess (2006), On Global Memory: Reactions on Barbaric Transmission (2009), and Beyond Photography (2009). Looking into these theoretical collections, we will be able to comprehend the part to which Bhabha belongs to. As the Europeans established the concept of colonization and intending on a civilizing mission - this is a situation where the Western culture as a superior culture, and it is placed over the colonized countries which are considered inferior (Armesto, 2006, p.133,23). For this reason, the invaded territories needed to be colonized by the European masters. Therefore, despite the concept of colonization, the culture of civilization and the colonized are seen as two different entities (Burns, 2001, p. 12).

Arab World English Journal for Translation \& Literary Studies 
This different cultural essentiality has created a distinction between the colonial masters and the colonized. It has also made some ideal class of nationalist discourse in terms of disparity in culture and identity. In this sense, for instance, in India, being one of the formerly colonized nations. M.K. Gandhi explains that Indian has lost its peculiar cultural value under the control of colonialism. This makes the indigenous Indians to start imitating the culture of the colonialists. (Gandhi, 2012, p. 23). Gandhi's national concept therefore reflects the principle of renaissance and rediscovery. This means going back to the previous cultural phenomenon of the pre-colonial era and, this is the representation of the period of cultural consecration. As it is, the cultural value of the colonized can be differentiated from the cultural identity of the colonizers, and this is where the main cultural sanctity becomes real. Mignolo explains that "... in the field of colonial literary studies, scholars must account for a complex system of semiotic interactions embodied in the discursive (oral) and the textual (material inscriptions in different writing systems), we need a concept such as colonial semiosis" (Mignolo, 1993, p. 126). Hence, to talk about Bhabha's cultural identity in this term, he believes that culture is not a permanent phenomenon because it is not an entity that can be created in time and space. Therefore, to Bhabha, culture is permanently motional. To him, it is a point of contact where different entities are sequentially bringing transformation to our cultural identities (Peter, 2001,157p. 25). As a result, he feels that there is no specific cultural identity such as having a complete Indianness, Africanness, or Britishness that can be particularly accepted or go back to.

\section{Findings and Discussion}

\section{Understanding the Idea of Culture and European Exploration}

To have a good understanding of this, let's take, for instance, one of the prominent European anthropologists, Bronisław Malinowski who had an adventure in the early 20th century to the Island of Papua New Guinea to investigate the natives in their primary cultural milieu. Bronisław Malinowski explains that these native people were the original owners of a uniquely distinct culture that has not been contaminated by any foreign interference (Olaussen, 2013, p. 65). But Bhabha has a contrary view on this notion of pure and unmixed culture- he claims it is a fanciful creation; that is, no culture has its original uniqueness without interfering some other cultures.

Therefore, he pontificates that all cultures have a way of being mixed with one culture or the other in which Bhabha terms as hybridity. But the issue here is that how can this Papuan Islanders culture be interfered with or polluted in any way? Hence, another prominent and contemporary anthropologist Jim Clifford in his work titled Traveling Culture, postulates on the claim of Malinowski of pure, unchanged, and unpolluted culture as just a fanciful creation; and there have been many scholars who have intensively written about the inhabitants of places that are very distant from the west and their writings are similar to what Malinowski opines. However, having critically looked into this notion of pure, unchanged, and unpolluted culture; if a Western anthropologist intends to travel to a remote area to study the other culture, the anthropologist connects the metropolitan to the field of the study he has gone to examine (Murdock,1943, p. 441). So, the notion that he cannot be polluted or influenced by the culture he has gone to study is an illusion. This anthropologist field of study is connected to other areas. So, the process of traveling from one geographical location to another is proof that any culture can be interconnected to another 
(Murdock, 1943, p. 442). Therefore, the notion of isolation of a culture cannot be truly possible in this aspect. So, as the anthropologist travels from one location to another, the detailed accounts of his study will eventually eliminate the notion of cultural pureness and unpollutedness. This is because the version of the study will create a nexus between the field of study and the metropolitan space. So, as the anthropologist travels,they are already connecting the urban sphere to the anthropologist location. The interconnection will not only be limited to geographical interconnection but there will also be a transcultural transposition.

Consequently, the field of study is secluded from the west; there has been a direct connection from the Western sphere to the remote areas of the study. In this sense, the notion of having a completely pure, static and unpolluted nature of culture is not absolute. It is very crucial to note that the anthropologist is communicating something to the people who inhabit the location where the study takes place. This means there is a certain level of translation taking place. In the course of this translation, the anthologist who is doing a research about the location tends to have an understanding of the native people, their cultural values and norms. As the anthropologist continues to write and research about the native people, the natives also tend to learn and understand the anthropologist, his nature and culture, and his society (Senft, 1997, p. 23). Subsequently, the issue of absolute cultural pureness becomes obsolete. And if the culture and the society are totally in isolation, there wouldn't be any such communication that will make them understand one another. As this has taken place, the cultural landscape of such a society can never be regarded as totally isolated and concealed (Gaillard, 2004, p. 30). Furthermore, it is sure that no culture has the quality of maintaining absolute purity and uncontaminated value, which means the culture, can never remain static without any interference of another culture(Gaillard, 2004, p. 139). Therefore, Bhabha's view regarding the cultural essence is that no culture can remain in its unchangeable state. But it can be categorized by change, motion, and transmogrification. Most importantly it be a mixture or inter-relationship which, and this is what Bhabha calls hybridity (Bhabha,1994, pp. 11-12).

\section{How Does the Idea of Cultural Hybridity Affect Our Understanding of postcolonial Situation?}

Hence, one may ask: how does the idea of cultural hybridity affect our understanding of postcolonial situations? Let's take, for instance, the European colonial repression of Africa, Bhabha posits that culture is unique and dynamic. It is full of transformation and interconnection. But looking at the binary of the superior culture of the West over Africa will mean talking about unchangeable and rigid cultural values (Bhabha, 1994, p. 130). But as we have been discussing the concept of hybridity, culture is always about changing and transforming procedures. Hence, the Europeans will not accept this notion because the purpose of cultural superiority is the soul of colonialism (Carvalheiro, 2010, p. 11). Unfortunately, what the colonial masters regarded as the superiority of their cultural identity began to evolve gradually in the rest decade of the 19th century, including the worth of their white skin color. But at the beginning of the 18th century, the issue of European domination and African inferiority was not glamourized because some of the Europeans nevr presented themselves as superior. They lived just like any other indigenes of the land. For example, when the British colonizers invaded India, there was no particular show-off of British superiority; neither was there any Indian inferiority complex — every British man was able 
to marry an Indian woman without any superiority or inferiority propensity. Yan Sayegh explains that "One of the major contemporary theorists recently associated with cultural hybridity is Homi Bhabha.

In most of his works, Bhabha reveals the interrelations and interdependence between the colonizers and the colonized" (Yan Sayegh, 2008, p.2). Therefore, the British did not bring with them any concept of superiority or elevated British idiosyncrasy still, such an attitude later evolved of exploitation of materialism, which eventually led to the justification of colonialism. Later on, the idea of British superiority to the Indian inferiority concept was also a creation of this same colonial subjugation. Looking into this idea, the design of the concept of Western cultural superiority evolved as a tool of colonization and civilizing instrument. But the main purpose of the civilizing concept is to be able to culturally influence the colonized people so that they would attain the level of civilization just like the colonizers (Hall, 1992, p. 252). For instance, in Africa, when the colonizers newly arrived on the continent, they made the colonized Africans believe that they were inferior to them, and they (the colonizers) were superior. And their primary purpose of colonization was to civilize the people because they were considered savages. The truth is that the African natives were convinced to believe and accept what they told them about them. This happened because when the colonizers colonized the people, they also colonized their psyches. This civilizing concept is a potent weapon used to subjugate the entire Africa and other invaded parts of the world where the colonial system was established. Therefore, the civilizing idea is a weapon to justify the concept of colonization (Dirlik, 1997, p. ix) as the colonized people continued to learn from the Western "superior" concept, they would be elevated to civilization like the colonizers. Notwithstanding, if we look into the idea of postcolonialism, it has developed to neocolonialism, which has taken another form of colonialism - beginning from where the previous one stopped. The propensity to dominate and gain absolute power has become the norm in most of the decolonized nations. Despite that, they had tried all their efforts to resist colonial power; they embraced it by establishing their indigenous, colonial system.

\section{European Expansionism}

The pre-colonial period has been an exciting discourse, though most of the reality of the pre-colonial period was hidden. But before the arrival of the European powers in their invaded locations, the natives had many ways of doing their things, and managed their affairs with an organized design. But when the Europeans arrived there, they established their system. Although, when they came, they did not reveal themselves as colonizers, as businessmen, and eventually, the civilizing and colonizing mission evolved; this is the main advent of European expansionism (Cannadine, 2003, p. 10). Hence, around the 1870s and 1900, the natives encountered a lot of Western colonial violence, diplomatic aggression, military attacks, and eventual victory and colonial dominance. At this moment, the natives tried as much as possible to resist the European invasion; they did not want them to invade and colonize them and establish their Western hegemony. For example, this expansionist concept came to Africa. And at the beginning of the 20th century, many African countries except Ethiopia and Liberia had been overpowered and brought under the Western Colonial powers and control.

Arab World English Journal for Translation \& Literary Studies 
There are three main factors that motivated the Western idea of colonial rule in Africa: Political, social, and economic factors. This began to evolve in the 19th century when the slave business started collapsing,and also because of the Western industrial, and the capitalist revolution that was taking effect (Chandler, 2006, p. 23). The importance of the capitalist industrial revolution includes the need for getting raw materials, the quest for a credible business, and lucrative investment. This led to the European expansion of power across the globe. However, the other motivating factors play a very significant role in the process. The political drive gotten from the effect of interEuropean power tussle and competition became very glaring and pronounced. Britain, Germany, France, Portugal, Italy, and Spain competed among themselves. Therefore, one of the most critical factors in proving political and national superiority is to expand territory across the globe, including the Africa continent.

The European power then continued their mission of expansionism through a forceful concept that involved intense competition (Jacques, 2012, p.g.12). The third major factor was the social aspect. Because of the industrial revolution, there were many serious social problems in Europe: poverty, unemployment, homelessness, and gregarious displacement from rural locations etc., became significant problems. These social challenges grew as a result of the incapability of some set of people who found it difficult to adjust to the new capitalist industrialization (Rawlinson, 2016, p. 12). So, one of the main ways of resolving this problem is to invade territories and establish colonial rules there. Through that, they would be able to export the populace of the invaded territory to Europe for cheap labor.This developed to create a colonial rule in countries like Tunisia, South Africa, Algeria, Namibia, Angola, Zambia, Zimbabwe, and the Central African Republic. Eventually, the economic factor became the main reason for colonizing the other parts of the world. Therefore, it is the political, economic, social factors that made most of the part of the world a colonized territory. Eventually, European powers established their imperialist system across the globe (Tzu, 2005, p. 23). The European powers began to compete with themselves. There was a declaration of absolute ownership of a particular territory. There was an establishment of powerful military might. They imposed tariffs against one another, and they had total control of waterways and economic routes in various parts of their territories. This competition among the European powers became intense that it generated some concern and fear that it might lead to severe conflict and even war (Tzu, 200, p. 23).

\section{Conclusion}

To sum up, regarding the colonial structure in a dominated area, the subjugated people would have no choice but to learn all the cultural values and identities of the colonizers. However, the primary mission of the civilizing concept is not just to civilize the colonized but to make them more and more become like the colonizers. The question is: can the colonized be like the colonizers? Even if there was a brainwashing mission, would they have taken away their identities? If this was going to be possible, it means there would be an extreme inculcation of the Western culture and language into the natives. There will be a total Westernization. More so, if this happened, then there wouldn't be any civilizational and cultural difference between the colonized and their colonizers. If this were in the contrary, it would destroy the concept that colonization was meant to civilize the subjugated people. But according to Bhabha, the colonized tried to mimic the colonizers, and they never expected that the colonized would quickly adapt to the culture they were trying to 
emulate.This act of mimicry becomes making jest of the superior culture. This article explores the interconnection between postcolonial study, superior and inferior cultures, hybridity, and colonialism. Further studies could be on examining the tool of colonialism in decolonized countries.

\section{About the Author:}

Waleed Pirbal Hamad is an Assistant Lecturer from Erbil, Iraq. His Master's Degree is in English Literature from Cyprus International University, North Cyprus (2016), and his current research interests focus on novels and literary criticism. ORCiD ID https://orcid.org/0000-0002-9550-0037

\section{References}

Abu-Lughod, J. L. (1991). Before European hegemony: the world system AD 1250-1350. Oxford University Press, USA.

Anderson, J. M. (2000). Writing in subjugated knowledges: Towards a transformative agenda in nursing research and practice. Nursing Inquiry 7(3): 145-145.

Anderson, J. M. (2000). The history of Portugal. Greenwood Publishing Group.

Armesto, F. (2006). Pathfinders: A Global History of Exploration. W.W. Norton \& Company.

Arnold, D. (2002). The Age of Discovery, 1400-1600, Lancaster pamphlets. Routledge.

Ashcroft, B., Griffiths, G., \& Tiffin, H. (2013). Post-colonial studies: The key concepts. routledge.

Bhabha, H. K. (2004). "The Black Savant and the Dark Princess." ESQ: A Journal of the American Renaissance, 50 (1), 137-155. Project MUSE.

Bhabha, H. K. (1994). The Location of Culture, Routledge.

Bhabha, H. K. (2009). On global memory: Reflections on barbaric transmission. In Crossing Cultures: Conflict, Migration, and Convergence: The Proceedings of the 32nd International Congress in the History of Art. Miegunyah Press.

Bhabha, H. K. (2012). "Beyond Photography." In A Living Man Declared Dead and Other Chapters I-XVIII, 7-21. New York: Gagosian Gallery.

Brook, T. (2007). Vermeer's Hat: The Seventeenth Century and the Dawn of the Global World (reissue ed.). Bloomsbury Press.

Cannadine, D. (2003). Ornamentalism: How the British saw their empire. Oxford University Press, USA.

Chandler, D. C. (2006). Empire in denial: the politics of state-building. Pluto.

De Castro, J. E. (2014). Colonialism and Postcolonialism. Gale Virtual Reference.

Dirlik, A. (1997). The Postconial Aura: Third World Criticism in the Age of Global Capitalism. Boulder: Westview Press.

Donkin, R. A. (2003). Between east and west: the Moluccas and the traffic in spices up to the arrival of Europeans. Memoirs of the American Philosophical Society, Diane Publishing.

Gandhi, M. (2012). The essential Gandhi: an anthology of his writings on his life, work, and ideas. Vintage.

Genoni, P. (2004). Subverting the Empire: Explorers and Exploration in Australian Fiction. Altona, VIC: Common Ground.

Hall, G., \& Wortham, S. (1996). Rethinking authority: interview with Homi K. Bhabha.

Hallward, P. (2001). Absolutely postcolonial: Writing between the singular and the specific. Manchester University Press. 
Huddart, D. (2006). Homi K. Bhabha. Routledge.

Jacques, M. (2009). When China rules the world: The end of the western world and the birth of a new global order. Penguin.

Mignolo, W. D. (1993). Colonial and postcolonial discourse: cultural critique or academic colonialism?. Latin American Research Review, 28(3), 120-134.

Rawlinson, K. (2016). Cecil Rhodes statue to remain at Oxford after 'overwhelming support'. The Guardian, 29.

Sen, T. (2016). The impact of Zheng He's expeditions on Indian Ocean interactions. Bulletin of the School of Oriental and African Studies, 79(3), 609-636.

Senft, G. (1999). Bronislaw Kasper Malinowski. In Handbook of pragmatics: 1997 installment. Benjamins.

Thornton, R. J., \& Skalník, P. (Eds.). (1993). The early writings of Bronisław Malinowski. Cambridge University Press.

Tzu, S. (2005). The Art of War (trans Thomas Cleary). Boston and London: Shambhala. 